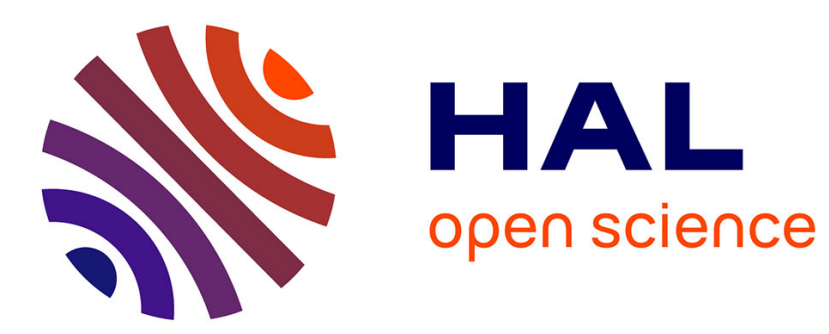

\title{
Proteome modifications of the medicinal leech nervous system under bacterial challenge
}

D. Vergote, E. Macagno, M. Salzet, Pe. Sautière

\section{To cite this version:}

D. Vergote, E. Macagno, M. Salzet, Pe. Sautière. Proteome modifications of the medicinal leech nervous system under bacterial challenge. Proteomics, 2006, 6 (17), pp.4817 - 4825. 10.1002/pmic.200500902 . hal-00086903

\section{HAL Id: hal-00086903 https://hal.science/hal-00086903}

Submitted on 18 Aug 2007

HAL is a multi-disciplinary open access archive for the deposit and dissemination of scientific research documents, whether they are published or not. The documents may come from teaching and research institutions in France or abroad, or from public or private research centers.
L'archive ouverte pluridisciplinaire HAL, est destinée au dépôt et à la diffusion de documents scientifiques de niveau recherche, publiés ou non, émanant des établissements d'enseignement et de recherche français ou étrangers, des laboratoires publics ou privés. 


\section{IMMUNE RESPONSE OF AN INVERTEBRATE NERVOUS SYSTEM:}

\section{A PROTEOMIC STUDY IN THE MEDICINAL LEECH}

David Vergote $^{1}$, Eduardo R. Macagno ${ }^{2}$, Michel Salzet ${ }^{1}$, and Pierre-Eric Sautière ${ }^{1^{*}}$

${ }^{1}$ Laboratoire de Neuroimmunologie des Annélides, FRE CNRS 2933, IFR 118 INSERM, Université des Sciences et Technologies de Lille, 59655 Villeneuve d'Ascq, France, and ${ }^{2}$ Section of Cell and Developmental Biology, Division of Biology, University of California, San Diego, La Jolla, CA 92093, USA.

Running title: Immune response of the leech nervous system

"to whom correspondence should be addressed:

Dr. P.-E. Sautière,

Laboratoire de Neuroimmunologie des Annélides, FRE CNRS 2933,

SN3, Université des Sciences et Technologies de Lille, 59655 Villeneuve d'Ascq, France,

Phone: (33) 3204341 28/Fax: (33) 320434054

E-mail: pierre-eric.sautiere@univ-lille1.fr

Abbreviations: CNS, central nervous system; ER, endoplasmic reticulum; NCS, Neuronal calcium sensor; PDI, protein disulphide isomerase. 
Keywords: innate immunity, nervous system, invertebrates, leech, proteomics 


\section{Abstract}

At first considered an organ lacking intrinsic immune mechanisms, the central nervous system of vertebrates is now known to be capable of mounting its own innate immune response. Interestingly, while invertebrates have been very useful in the interpretation of general vertebrate innate immunity mechanisms, only scarce data are available on the immune response of nervous tissue within this group. This study provides new data on the innate immune response of the central nervous system (CNS) of the medicinal leech Hirudo medicinalis. We identified several spots in twodimensional gels of leech CNS proteins that showed specific changes following bacterial challenge, thus demonstrating the ability of the leech nervous system to mount a response to an immune stress. Protein identifications were based on comparison of sequence data with publicly available databases and a recently established leech expressed sequence tags (ESTs) database. The broad nature of the identified proteins suggests a clear involvement of cytoskeletal rearrangements, endoplasmic reticulum stress, modulation of synaptic activity and calcium mobilization, all during the 24 first hours of this response. Moreover, several of these proteins are specifically expressed in glial cells, suggesting an important role for glial cells in the immune response of the leech nervous system, similar to what has been observed in vertebrates. 


\section{Introduction}

Invertebrates, because of their relative simplicity and accessibility, are very useful and broadly applicable models for the detailed analysis of multiparametric mechanisms underlying the physiology of tissues, organs and whole organisms. In many instances, studies in invertebrates have thrown light on complex mechanisms not well understood and difficult to study in vertebrates. Indeed, studies of immune mechanisms in invertebrates have yielded information critical to the understanding of innate immunity in both invertebrates and vertebrates $[1,2]$. For example, insects have played a seminal role through the initial characterization in Drosophila melanogaster of toll receptors and their signalling pathways via transcription factors of the rel family $[3,4]$ prior to the characterization of similar vertebrates factors $[5$, 6]. With respect to the invertebrate nervous system, however, little is known at the present time about its immune responses. Among the few reported examples are the recent studies by Pujol et al. [7], who have reported the involvement of the tol-1 gene, expressed in pharyngeal neurons and homologous to toll genes of $D$. melanogaster, in the pathogen avoidance behaviour of the nematode Caenorhabditis elegans. In the case of Aplysia californica long-term hyperexcitability of sensory neurons has been shown to be induced by lipolysaccharides and inflammation [8], and a role for nitric oxide in the nervous system of the immune-stressed Planorbarius corneus has been suggested by the increased expression of nitric oxide synthase induced upon lipolysaccharide challenge [9]. Nevertheless, much needs to be done 
before a comprehensive understanding of innate immunity in the invertebrate nervous system is achieved.

In this context, we recently began to explore the responses of the leech central nervous system (CNS) to bacterial challenge [10]. The medicinal leech Hirudo medicinalis, a member of the Lophotrochozoan family, has been intensively studied since the XIX century $[11,12]$. Its ventral CNS has been studied in great detail,,and many of the $\sim 400$ neurons per segmental ganglion, have been morphologically and physiologically characterized [13]. The development of the nervous system is also well documented [14], as is its capacity to regenerate accurate and functional synaptic connections after nerve damage [15-17]. Because so much is already known about the properties of the normal embryonic and adult CNS, the medicinal leech is recognized as an important model system in neurobiology and hence is also an excellent system for the investigation of the mechanisms underlying the neuronal response to bacterial challenge.

In this study, we used a 2D-SDS-PAGE-based proteomic analysis to investigate the response of the CNS of $H$. medicinalis to an immune challenge. As a consequence of bacterial exposure, we detected significant changes in the representation of several proteins in the leech nervous system. While only sparse genomic data is available for the leech in public databases, we were able to use a recently established leech ESTs database to identify most of the modulated proteins using mass spectrometry tools. To our knowledge, this is the first report of a global 
analysis of the innate immune response specifically within the nervous system in invertebrates.

\section{Experimental procedures}

Animals - Adult $H$. medicinalis specimens were obtained from Ricarimpex (Eysines, France) and kept in artificial pond water for acclimatization for at least one week prior to experimental use.

Two-dimensional gel electrophoresis - H. medicinalis CNSs were dissected out in leech Ringer $\left(115 \mathrm{mM} \mathrm{NaCl}, 1.8 \mathrm{mM} \mathrm{CaCl}_{2}, 4 \mathrm{mM} \mathrm{KCl}, 10 \mathrm{mM}\right.$ Tris maleate, $\mathrm{pH}$ 7.4) and bathed ex vivo in PBS-based medium with (septic conditions) or without (control conditions) $2 \times 10^{8}$ bacteria from a cocktail of Gram-positive and -negative bacteria (Escherichia coli/Micrococcus luteus) for 1, 6, 12 or $24 \mathrm{hrs}$ before being frozen in liquid nitrogen. To avoid inter-individual variations, each gel was prepared from a batch of ten control or ten experimental nerve chains receiving the same treatment. Four gels were then prepared for each condition, from four different batches of nerve chains, according to the 2-D gel electrophoresis protocol previously described [10]. Briefly, protein extractions consisted of freezing/defrosting cycles, ultrasonic extraction, trichloroacetic acid/acetone precipitation and resuspension in lysis buffer (9.5 M urea, 2\% Triton X-100, $65 \mathrm{mM} \beta$-mercaptoethanol, 1.25\% SDS)

[18]. The protein concentration of each sample was determined using the Peterson 
method [19]. Isoelectrofocusing for the 2-D gel electrophoresis was performed using the IEFCell system (Biorad). Immobilized $\mathrm{pH}$ 3-10 linear gradient strips were rehydrated in a reswelling solution containing $9 \mathrm{M}$ urea, 2\% Triton X-100, $10 \mathrm{mM}$ DTT, 0.2\% v/v Bio-lyte (pH 3-10 : pH 5-8 : pH 7-9, 1:1:2, Biorad) and extracted leech nervous system proteins. After rehydration, IEF voltage was raised gradually to $8000 \mathrm{~V}$ and gels were run at $20^{\circ} \mathrm{C}$ until reaching $180000 \mathrm{~V}$.hr. After focusing, proteins were reduced and subsequently carbamidomethylated with $130 \mathrm{mM}$ DTT and with $135 \mathrm{mM}$ iodoacetamide, respectively, in $6 \mathrm{M}$ urea, $375 \mathrm{mM}$ Tris- $\mathrm{HCl}, 2 \%$ SDS, 20\% glycerol, 0.02\% Coomassie blue G-250, pH 8.8 [20]. Second dimensions were run on $12 \%$ polyacrylamide/ $0.8 \%$ piperazine diacrylamide in Tris/Tricine buffer as described by Schägger and von Jagow [21]. After electrophoresis, gels were silver stained according to a modified protocol of Morrissey [22] or Coomassie blue stained according to Neuhoff [23].

2-D gel image analysis - Four silver-stained gels per condition were analyzed using the Progenesis ${ }^{\mathrm{TM}}$ v1.5 software program (Nonlinear Dynamics, Newcastle upon Tyne, UK). The analysis protocol included spot detection and filtering, whole image warping on a reference gel, background subtraction, average gel creation and spot matching. Each analysis step was manually validated. In creating the gel average, one spot absence in the gel series was allowed. To minimize intergel staining variation due to silver staining, a final volume normalization step against the total volume of all protein spots present in the gel was performed. Statistical analyses were performed using GraphPad Instat version 3.0 (GraphPad software) for an ANOVA test across 
the kinetic of stimulation ( $\mathrm{p}$ values of less than 0.05 were considered significant). Only statistically significant changes in spot representation with a 1.4 factor or higher were analyzed further.

Edman degradation - Spots were excised and eluted as described by Shaw [24] from Coomassie blue stained 2-D electrophoresis gels. $\mathrm{NH}_{2}$-terminal amino-acid sequencing was performed on a pulse-liquid automatic peptide Perkin Elmer/Applied Biosystems Procise cLC-492 microsequencer.

In-gel digestion for mass spectrometry analysis - Polyacrylamide gel pieces of Coomassie blue stained proteins were washed in $25 \mathrm{mM}$ ammonium bicarbonate $/ 50 \%$ acetonitrile. Digestion in protease solution (sequence grade modified trypsin, Promega, at $0.02 \mathrm{mg} / \mathrm{ml}$ in $25 \mathrm{mM}$ ammonium bicarbonate) was performed overnight at $30^{\circ} \mathrm{C}$. Peptides were extracted twice for $15 \mathrm{~min}$ with $50 \%$ acetonitrile $/ 1 \%$ trifluoroacetic acid. Trypsin digests were then lyophilized and resuspended in $5 \mu 1$ of $0.1 \%$ trifluoroacetic acid.

MALDI-TOF MS analysis - MALDI-TOF MS analysis of trypsin digests was performed on a Voyager DE Pro (Applied Biosystems) in reflector mode as described elsewhere [10]. Protein database searching was performed using MS-Fit (http://prospector.ucsf.edu/ucsfhtml4.0/msfit.htm) according to the monoisotopic molecular weight of $[\mathrm{M}+\mathrm{H}]^{+}$peptides ions.

NanoESI-q-ToF analysis - After desalting the samples on a C18 Zip-Tip (Millipore, Bedford, MA, USA), trypsin digests were loaded into nanoES capillaries (Protana, Odense, Denmark). The capillaries were inserted into an Applied Biosystems Q- 
STAR Pulsar (Q-TOF-MS) using an ion spray source. Doubly charged peptides were selected, fragmented by $\mathrm{N}_{2}$ collision and analysed by nanoESI-q-TOF. Peptides sequences were manually assigned and sequences with a minimum of 5 consecutive residues were searched against both eukaryotic and prokaryotic sequence data from available databases using MSblast software (http://dove.emblheidelberg.de/Blast $2 / \mathrm{msblast}$.html) as described previously [25], the significance of the hits were defined according to Altschul et al. [26] and against a $H$. medicinalis EST (whole embryo and adult CNS) database that is currently under construction by our laboratories. (http://leechmaster.ucsd.edu/).

Western blot - Western blot were performed from 2D gels loaded with $1 \mathrm{mg}$ of proteins prepared as described above. Proteins were then transferred to a PVDF membrane in a 3-cyclohexamino-1-propanesulfonic acid buffer $(10 \mathrm{mM}, \mathrm{pH} 11)$ containing $10 \%$ of methanol according to a modified protocol of Matsudaira [27]. Membranes were treated with 5\% skimmed milk in PBS prior probing with polyclonal anti-neurohemerythrin antiserum (1:5000 dilution, [10]), in 5\% skimmed mild in PBS- $0.5 \%$ Tween-20 overnight at $4^{\circ} \mathrm{C}$. Membranes were then washed and incubated with goat anti-rabbit secondary antibody conjugated to HRP (1:10000 dilution, Jackson). After extensive washes, the peroxidase activity on the membrane was detected by chemiluminescence (GE Healthcare). 


\section{Results}

In this study, we examined the molecular responses of the leech CNS to bacterial challenge by comparing electrophoretic profiles of ganglionic chains incubated in PBS-based medium with or without bacteria for different periods of time. A representative 2-D gel of extracted leech nerve cord proteins is shown in Figure 1. Our 2-D gel electrophoresis protocol allows the detection of approximately 580 spots on these gels. Among the spots, 15 were significantly modulated at least at one time point $(1,6,12$ or $24 \mathrm{hrs})$ between septic and control conditions $(\mathrm{p}<0.05$, ANOVA test; Table I, Figure 1 and 2). Edman degradation and mass spectrometry tools were used to identify the modulated proteins. Although we tried to obtain the terminal sequence for each modulated spot by Edman degradation, only one sequence was obtained (GFEIPEPYVWDE for the spot 2802). This might be due either to low recovery of proteins from the gel or to non-accessible $\mathrm{NH}_{2}$-terminal residues preventing proteins from being sequenced at the $\mathrm{NH}_{2}$-terminal.

Because of the paucity of genomic data for $H$. medicinalis, a MALDI-TOF analysis of tryptic digests was not sufficient to identify leech proteins. Consequently, sequences or tags were obtained by nanoESI-q-TOF (supplemental table), and were compared with publicly available databases using MSblast software (http://dove.embl-heidelberg.de/Blast2/msblast.html) and with a H. medicinalis EST database (http://leechmaster.ucsd.edu/). We identified 9 proteins among the 15 
represented differentially (see Table I, supplemental figure 1, and Figure 3). Identified proteins belong to very diverse families of proteins, including cytoskeletal proteins, endoplasmic reticulum stress proteins, proteins involved in metabolic pathways, a calcium-binding protein, and an iron oxygen-binding protein.

After a period of immune challenge as short as one hour, we detected the modulation of cytoskeletal proteins. Indeed, sequences obtained for the spot 1528 , which is significantly modulated up and down during the $24 \mathrm{hr}$ time-course of the experiments (Table I), allowed us to isolate a clone from the leech EST database showing $77 \%$ identity with Haliotis asinina tropomyosin (Supplemental data). In addition, peptide sequences obtained from spot 1759 (upregulated after $1 \mathrm{hr}$ of bacterial exposure) are specific to gliarin, a protein previously described in $H$. medicinalis glial cells [28]. These proteins are representatives of two of the three types of cytoskeletal filaments (microfilaments and intermediate filaments, respectively) $[29,30,28]$.

Spot 2220, up-regulated after $6 \mathrm{hrs}$ of bacterial exposure, was identified as an endoplasmic reticulum stress protein of the cyclophylin family, a group of enzymes possessing, in addition to peptidyl-prolyl cis-trans isomerase activity, foldase and chaperone activities [31]. This protein has been tightly tied to the immune response, as some immunosuppressive drugs, such as cyclosporine A and FK506, act by forming a tertiary complex with the cyclophilin and the calcium/calmodulindependent protein phosphatase calcineurin $[32,33]$. Another foldase was identified among modulated spots, a protein of the protein disulphide isomerase (PDI) family 
(spot 1049), which was up-regulated after $24 \mathrm{hrs}$ of bacterial exposure. This enzyme is known to possess foldase and chaperone activities that could be involved in the modulation and maintenance of the tertiary structure of other proteins [31].

The comparative analysis of our 2-D gels also allowed us to detect changes in spot 1749. This spot was present in bacteria-stimulated nerve cords and absent in control nerve cords after $1 \mathrm{hr}$ of incubation, a pattern opposite to that observed after $24 \mathrm{hrs}$ of stimulation. A sequence obtained from this spot contains an EF-hand domain (DGEL'VL'DEFZK, where L' represents an I or a $\mathrm{L}$ and $\mathrm{Z}$ a $\mathrm{Q}$ or a $\mathrm{K}$ to be compared to the consensus sequence $\mathrm{F}(\mathrm{X})_{3} \mathrm{DXDXDGXI}(\mathrm{X})_{3} \mathrm{EF} \quad(\mathrm{CDD}$ pfam00036.11)). The same sequence allowed us to isolate a clone from the leech EST database. The overall sequence of that clone showed high homologies with the neuronal calcium sensor- 2 of $C$. elegans and with the neurocalcin of $D$. melanogaster (supplemental figure 2 or 3 ).

Also modulated along the time-course of septic challenge are enzymes involved in metabolic pathways. These enzymes are represented by spot 1164 (upregulated after $1 \mathrm{hr}$ of sepsis) identified as the $\beta$ subunit of an ATP synthase (figure 3), a component of the basic mitochondrial machinery responsible for energy production [34], and by spot 1155 (down-regulated after 6 and $24 \mathrm{hrs}$ of sepsis), identified as an aminoacyl dehydrogenase, an enzyme involved in amino acid metabolism. Besides these two proteins, sequence data obtained for spot 1585 (first down- then up-regulated after 1 and $6 \mathrm{hrs}$ of stimulation, respectively) identified this 
protein as an acetyl transferase, an enzyme able to modulate the function of others proteins by acetylation of the amino group of their lysyl residues [35].

We have previously reported the characterization of the 6 hour-up-regulated spot 2802 [10]. The up-regulation of this spot was confirmed by Western blotting (Supplemental fig 3 or 4 ). We were able to obtain the entire coding sequence of this protein, showing a high level of similarity to members of the hemerythrin family. Hemerythrins are non-heme-iron oxygen-transport proteins whose oxygen binding properties via two iron atoms have been described thus far [36]. We called this protein neurohemerythrin according to its cellular localization in the leech central nervous system, specifically within glial cells [10].

Thus far, we have not been able to identify others spots modulated in the course of the experiment either because of an insufficient amount of protein to obtain useful mass spectra or because of the lack of sequencing data concerning leech proteins for comparison. ,The sequences obtained for these spots are reported in the supplemental data table as well. 


\section{Discussion}

The goals of this study were (i) to set up optimal conditions before attempting a more focused analysis, and (ii) to provide new data about the intrinsic immune response of a Lophotrochozoan nervous system. From a technical point of view, our 2D-electrophoresis conditions allowed us to obtained well defined spots on gels. However, most protein spots had a pI between 5 and 7 . The gel resolution might thus be improved by using other IEF strips focusing on that $\mathrm{pI}$ range. Moreover, $70 \%$ of observed changes occurred at short time points ( 1 and $6 \mathrm{hrs}$ ). It will be interesting, then, to focus future neuroimmune studies of the leech on those time points.

In parallel with defining optimal conditions for further studies, we observed changes in spot representation specifically associated with the bacterial challenge. The analysis of the bacteria-induced changes in the protein profiles of nerve cords showed that aspects of the physiology of the nervous tissue are disturbed during sepsis and that the leech was able to set up an intrinsic neuroimmune reaction in response to the bacterial challenge. In the present work, we identified several protein families involved in this response. The observation that representatives of two types of cytoskeletal filaments are modulated suggests that significant cytoskeletal rearrangements occur within one or several cell type(s) within the leech CNS as soon as after one hour of immune challenge, and all along the first $24 \mathrm{hrs}$. The modulation of a tropomyosin, a protein associated with and regulating the stability of actin 
microfilaments $[30,37]$, suggests that, following the exposure to a septic challenge, microfilaments undergo destabilization or stabilization all along the time course, thus facilitating or inhibiting cytoskeletal rearrangements. Although intermediate filament components are very diversified in their amino acid sequences, most of them are considered as good markers of glial cell proliferation, as GFAP is for vertebrate astrocytes [38-40]. Gliarin could thus be a new marker of proliferation and maturation of leech glial cells and its up-regulation could reflect a glial activation in response to the immune challenge. These rearrangements could be associated with morphological changes (such as neurite regeneration and/or phagocytosis) and the migration of cells. Indeed, it has been shown that leech microglial cells are able to migrate within the ganglionic chain to the site of a lesion and that they could have phagocytic activity that also involves cytoskeletal rearrangements [41].

The identification of a down-regulated aminoacyl dehydrogenase (spot 1155) suggests a regulation of amino acid metabolism, particularly of excitatory amino acids playing a role as neurotransmitters within the nervous system and hence a regulation in synaptic activity. Moreover, it is well known that, in vertebrate brains, excess of excitatory amino acids leads to an increase of calcium release within neurons and to the phenomenon of excitotoxicity responsible for neuronal death [42, 43]. Interestingly, we also report here the modulation of a protein able to bind calcium during the course of the immune response of the leech nervous system (a neurocalcin-like protein of the NCS family), showing that calcium is probably involved in this response. The physiological role of the neurocalcin is unclear, but 
this protein was found in the neuropiles of brain and thoracic ganglia in the fruitfly, where most of the synaptic connections are located [44]. This also suggests a potential role for neurocalcin in synaptic activity and particularly in vesicular trafficking, due to its property to bind to cytoskeletal proteins like actin filaments and microtubules $[44,45]$. A role as general regulator of $\mathrm{G}$ protein-coupled receptor kinase and adenylate and guanylate cyclase pathways for the NCS family has also been described $[46,47]$. It will be interesting to further investigate the involvement of these pathways in response to immune challenge in the leech, particularly in regard to the involvement of other NCS, like recoverin, in neurodegenerative diseases [48]. If neurodegeneration does occur within the leech nervous system following septic shock, a candidate for its regulation, along with the NCS protein, could be the increase in ATP production that would follow from the change observed in the $\beta$ subunit of an ATP synthase (spot 1164). This change could influence apoptosis/necrosis balance and thus inflammation in the nervous tissue [43]. Moreover, up-regulation of the ATP synthase subunit suggests that at least a part of the observed changes require energy, so that the neuroimmune response of the leech nervous system involves active phenomenon.

Another mechanism induced by sepsis in the leech nervous system is suggested by the increase in ER stress proteins representation (spots 1049 and 2220) on gels after 1 and $6 \mathrm{hrs}$ of stimulation. Indeed, PDIs and cyclophilins are enzymes of the foldase family involved in the maintenance of the tertiary structure of proteins [49]. These enzymes are known to be involved in the unfolded protein response 
mounted following ER stress brought about the accumulation of misfolded proteins [50]. This unfolded protein response regulates the initiation of apoptotic processes and is a critical mechanism for maintaining nervous system functions in low-stress conditions or for inducing cellular death in high-stress conditions [51]. Moreover, a functional link between cyclophilin and calcineurin have been reported [33]. Inhibition of this phosphatase with immunosuppressive drugs prevents nuclear translocation of transcription factors and thus the expression of genes associated with the immune response [52]. Besides cyclophilin, acetyl transferase is also able to modulate gene transcription. Indeed, known targets of acetyl transferase, other than cytoskeletal proteins, are proteins regulating gene expression, either histones or transcription factors $[35,53]$. It has been shown that $\mathrm{NF \kappa B}$, a major transcription factor involved in immune responses, could be acetylated and that this acetylation would allow NFkB to remain within the nucleus, resulting in an enhanced activation of immune gene expression [35]. According to these observations, cyclophilin and acetyl transferase might be significant regulators for the activation of genes involved in the leech CNS intrinsic immune response.

Finally, properties of neurohemerythrin have led us to propose several putative functions for this protein in the response of the leech nervous tissue: (i) a role as an oxygen supplier for metabolism, (ii) a role as a trap for reactive oxygen species and NO protecting cells from cell death, and (iii) a role as an antibacterial factor depriving bacteria of iron [10]. 
The work presented here represents an early step toward a better understanding of the molecular mechanisms subtending the innate immune response of the leech nervous system and, generally speaking, of invertebrate nervous systems. Our results show that the leech CNS is able to respond in an intrinsic manner to a septic stimulus, mounting a neuroimmune response. Careful study of potential roles of the identified proteins will be essential to fully understand the mechanisms involved, but some candidate mechanisms can be proposed on the basis of the proteins identified in this study: (i) cytoskeletal rearrangements potentially responsible for morphological changes, cell migration, vesicular trafficking and/or phagocytosis, (ii) modulation of synaptic activity, (iii) calcium involvement, and (iv) unfolded protein response controlling the functionality of proteins affected by the stress generated by the sepsis. The involvement in innate immunity of some proteins or protein families we identified here has previously been described in insect [54-57] and annelids [58] by proteomic and transcriptomic studies but at the peripheral level and not within the nervous system (Table II). Moreover, the overall protein families we found involved in the immune response of the medicinal leech nervous system are also involved in nerve regeneration, as shown by Blackshaw et al, also in the medicinal leech [59] and by Perlson et al in Lymnaea stagnalis [60] (Table II). These observations suggest (i) a great conservation of mechanisms involved in peripheral and central innate immunity within invertebrates and (ii) that some of the same families of proteins, and perhaps the same mechanisms, might be involved in both innate neuroimmunity and regeneration of the nervous system. 
Finally, since at least two of the modulated proteins (neurohemerythrin and gliarin) are specifically expressed in glial cells, these cells may be particularly involved in the immune response of the leech nervous system, as they are in vertebrates. Moreover, it has been shown that microglial cells of the leech are able to migrate within the nervous system after a crush to the site of injury and that they could have phagocytic activity, for which cytoskeletal rearrangements are also required $[41,61]$. These observations hint at a possible involvement of glial cells in nervous system immunity, a role we plan to explore in future experiments. 


\section{References}

[1] Hoffmann, J. A., Kafatos, F. C., Janeway, C. A.Ezekowitz, R. A., Science 1999, 284, 1313-1318.

[2] Khush, R. S.Lemaitre, B., Trends Genet 2000, 16, 442-449.

[3] Lemaitre, B., Nicolas, E., Michaut, L., Reichhart, J. M.Hoffmann, J. A., Cell 1996, 86, 973-983.

[4] Imler, J. L.Hoffmann, J. A., Curr Opin Microbiol 2000, 3, 16-22.

[5] Chaudhary, P. M., Ferguson, C., Nguyen, V., Nguyen, O.et al., Blood 1998, 91, 4020-4027.

[6] Thoma-Uszynski, S., Stenger, S., Takeuchi, O., Ochoa, M. T.et al., Science 2001, 291, 1544-1547.

[7] Pujol, N., Link, E. M., Liu, L. X., Kurz, C. L.et al., Curr Biol 2001, 11, 809821.

[8] Farr, M., Mathews, J., Zhu, D. F.Ambron, R. T., Learn Mem 1999, 6, 331340.

[9] Peruzzi, E., Fontana, G.Sonetti, D., Brain Res 2004, 1005, 9-20.

[10] Vergote, D., Sautiere, P. E., Vandenbulcke, F., Vieau, D.et al., J Biol Chem 2004, 76, 195-201.

[11] Ehrenberg, C. G., Beobachtungen einer auffallenden bisher unbekannten Structur des Seelenorgans bei Menschen und Tieren, 1836.

[12] Retzius, G., in: Biologische Untersuchengen, Neue Folge, 1891, 1-28.

[13] Macagno, E. R., J Comp Neurol 1980, 190, 283-302.

[14] Macagno, E. R., Peinado, A. Stewart, R. R., Proc Natl Acad Sci U S A 1986, 83, 2746-2750.

[15] Xie, Y., Yeo, T. T., Zhang, C., Yang, T.et al., J Neurosci 2001, 21, 51305138 .

[16] Emes, R. D., Wang, W. Z., Lanary, K.Blackshaw, S. E., FEBS Lett 2003, 533, $124-128$.

[17] Korneev, S., Fedorov, A., Collins, R., Blackshaw, S. E.Davies, J. A., Invertebrate Neurosci 1997, 3, 185-192.

[18] Damerval, C., De Vienne, D., Zivy, M.Thiellement, H., Electrophoresis 1986, 7, 52-54.

[19] Peterson, G. L., Anal Biochem 1977, 83, 346-356.

[20] Wu, X., Ritter, B., Schlattjan, J. H., Lessmann, V.et al., J Neurobiol 2000, 44, 320-332.

[21] Schagger, H.Von Jagow, G., Anal Biochem 1987, 166, 368-379.

[22] Morrissey, J. H., Anal Biochem 1981, 117, 307-310.

[23] Neuhoff, V., Arold, N., Taube, D.Ehrhardt, W., Electrophoresis 1988, 9, 255 - 
[24] Shaw, C., Thim, L.Conlon, J. M., J Neurochem 1987, 49, 1348-1354.

[25] Shevchenko, A., Sunyaev, S., Loboda, A., Bork, P.et al., Anal Chem 2001, 73, 1917-1926.

[26] Altschul, S. F., Madden, T. L., Schaffer, A. A., Zhang, J.et al., Nucleic Acids Res 1997, 25, 3389-3402.

[27] Matsudaira, P., J Biol Chem 1987, 262, 10035-10038.

[28] Xu, Y., Bolton, B., Zipser, B., Jellies, J.et al., J Neurobiol 1999, 40, 244-253.

[29] Westermann, S.Weber, K., Nat Rev Mol Cell Biol 2003, 4, 938-947.

[30] Pittenger, M. F., Kazzaz, J. A.Helfman, D. M., Curr Opin Cell Biol 1994, 6, 96-104.

[31] Wang, C. C.Tsou, C. L., FEBS Lett 1998, 425, 382-384.

[32] Galat, A., Curr Top Med Chem 2003, 3, 1315-1347.

[33] Liu, J., Albers, M. W., Wandless, T. J., Luan, S.et al., Biochemistry 1992, 31, 3896-3901.

[34] Leyva, J. A., Bianchet, M. A.Amzel, L. M., Mol Membr Biol 2003, 20, 27-33.

[35] Imhof, A., Yang, X. J., Ogryzko, V. V., Nakatani, Y.et al., Curr Biol 1997, 7, 689-692.

[36] Bates, G., Brunori, M., Amiconi, G., Antonini, E.Wyman, J., Biochemistry $1968,7,3016-3020$.

[37] Ono, S.Ono, K., J Cell Biol 2002, 156, 1065-1076.

[38] Fuchs, E.Weber, K., Annu Rev Biochem 1994, 63, 345-382.

[39] Gomes, F. C., Paulin, D.Moura Neto, V., Braz J Med Biol Res 1999, 32, 619-

631.

[40] Dyer, C. A., Kendler, A, Jean-Guillaume, D., Awatramani, R.et al., $J$ Neurosci Res 2000, 60, 412-426.

[41] Morgese, V. J., Elliott, E. J.Muller, K. J., Brain Res 1983, 272, 166-170.

[42] Barger, S. W.Basile, A. S., J Neurochem 2001, 76, 846-854.

[43] Brown, G. C.Bal-Price, A., Mol Neurobiol 2003, 27, 325-355.

[44] Teng, D. H., Chen, C. K.Hurley, J. B., J Biol Chem 1994, 269, 31900-31907.

[45] Ivings, L., Pennington, S. R., Jenkins, R., Weiss, J. L.Burgoyne, R. D., Biochem J 2002, 363, 599-608.

[46] Sallese, M., Iacovelli, L., Cumashi, A., Capobianco, L.et al., Biochim Biophys Acta 2000, 1498, 112-121.

[47] Burgoyne, R. D.Weiss, J. L., Biochem J 2001, 353, 1-12.

[48] Bataller, L.Dalmau, J., Curr Opin Neurol 2004, 17, 3-8.

[49] Frand, A. R., Cuozzo, J. W.Kaiser, C. A., Trends Cell Biol 2000, 10, 203-210.

[50] Imaizumi, K., Miyoshi, K., Katayama, T., Yoneda, T.et al., Biochim Biophys Acta 2001, 1536, 85-96.

[51] Xu, C., Bailly-Maitre, B.Reed, J. C., J Clin Invest 2005, 115, 2656-2664.

[52] Shaw, K. T., Ho, A. M., Raghavan, A., Kim, J.et al., Proc Natl Acad Sci U S A 1995, 92, 11205-11209.

[53] Kawahara, K., Kawabata, H., Aratani, S.Nakajima, T., Ageing Res Rev 2003, $2,287-297$. 
[54] Levy, F., Bulet, P.Ehret-Sabatier, L., Mol Cell Proteomics 2004, 3, 156-166.

[55] Loseva, O.Engstrom, Y., Mol Cell Proteomics 2004, 3, 796-808.

[56] Dimopoulos, G., Christophides, G. K., Meister, S., Schultz, J.et al., Proc Natl Acad Sci US A 2002, 99, 8814-8819.

[57] Vierstraete, E., Verleyen, P., Baggerman, G., D'hertog, W.et al., Proc Natl Acad Sci U S A 2004, 101, 470-475.

[58] Lefebvre, C., Cocquerelle, C., Vandenbulcke, F., Hot, D.et al., Biochem J 2004, 380, 617-625.

[59] Blackshaw, S. E., Babington, E. J., Emes, R. D., Malek, J.Wang, W. Z., J Anat 2004, 204, 13-24.

[60] Perlson, E., Medzihradszky, K. F., Darula, Z., Munno, D. W.et al., Mol Cell Proteomics 2004,

[61] Chen, A., Kumar, S. M., Sahley, C. L.Muller, K. J., J Neurosci 2000, 20 , 1036-1043. 


\section{Acknowledgements}

We would like to thank Eric Décout from Proteaxis (Loos, France) for allowing and helping us to use the Progenesis ${ }^{\mathrm{TM}}$ software. This work was supported by the CNRS, the Ministère de l'Education Nationale, de la Recherche et des Technologies, the FEDER, the Conseil Régional Nord-Pas-de-Calais, the Génopôle de Lille, the Plateau de Protéomique de l'Université des Sciences et Technologies de Lille and the NIHFogarty Grant. 
Table I: List of significantly modulated proteins after 1, 6, 12 or $24 \mathrm{hrs}$ of bacterial challenge in the leech CNS.

\begin{tabular}{ccccccccc}
\hline Spot & MW & PI & Access & Protein family & \multicolumn{3}{c}{ Bact./ctl. ${ }^{\text {b) }}$ spot representativity } \\
number & (kDa) & & number ${ }^{\text {a) }}$ & identification & $\mathbf{1 ~ h r}$ & $\mathbf{6 ~ h r s}$ & $\mathbf{1 2}$ hrs & $\mathbf{2 4}$ hrs \\
\hline 1049 & $55-60$ & $5.0-5.2$ & AJ005808 & PDI & - & - & - & $1.82^{* *}$ \\
1155 & $50-55$ & 6 & AAN69196 & Aminoacyl dehydrogenase & - & $0.63^{*}$ & - & $0.60^{*}$ \\
1164 & 50 & $5.1-5.2$ & Q25117 & $\beta$ subunit ATP synthase & $2.10^{*}$ & - & - & - \\
1528 & $36-38$ & 4.8 & P42637 & Tropomyosin & $0.62^{* *}$ & $1.89^{* * *}$ & - & $0.48^{* * *}$ \\
1585 & $35-37$ & $4.8-4.9$ & Q9U0U9 & Acetyl transferase & $0.29 * *$ & $3.53^{* * *}$ & - & - \\
1749 & $33-36$ & $6.9-7.0$ & NP_492651 & NCS & app & - & - & dis \\
1759 & $33-35$ & 5.9 & AAD29248 & Gliarin & $2.11^{*}$ & - & - & - \\
2220 & $22-24$ & $6.8-6.9$ & U92087 & Cyclophilin & - & $1.65^{*}$ & - & - \\
2802 & $14-15$ & 5.6 & AY521548 & Neurohemerythrin & - & $1.40^{*}$ & - & - \\
1726 & $33-36$ & $5.8-5.9$ & - & Unknown & - & $3.43^{* *}$ & - & - \\
1917 & $28-32$ & 7 & - & Unknown & - & $1.81^{*}$ & - & - \\
1932 & $28-32$ & $6.8-6.9$ & - & Unknown & $1.81^{*}$ & - & - & - \\
2090 & 25 & $7.5-8.0$ & - & Unknown & - & - & $0.27^{* * *}$ & - \\
2144 & $23-25$ & 5.8 & - & Unknown & - & $1.86^{* * *}$ & - & - \\
2256 & $21-23$ & 5.3 & - & Unknown & - & - & $2.32^{* * *}$ & -
\end{tabular}

$\overline{\text { Spot numbers, experimental molecular weights (MW) and pI, protein identifications }}$ and modulation ratios of spot between bacterial-challenged and control leech central nervous system are indicated. ${ }^{\text {a) }}$, access number of the first significant match after database searching; b), Bacteria/control spot representativity; Unknown, no identification allowed from data obtained; * $\mathrm{p}<0.05 ; * *, \mathrm{p}<0.01 ;{ }^{* *}, \mathrm{p}<0.001 ;$ - no significant change; app, spot present in stimulated but absent in control CNS; dis, spot absent in stimulated but present in control CNS. 
Table II: Similarities between proteins involved in innate immunity within invertebrate and those involved in central nervous system regeneration within Lophotrochozoaria, all identified by proteomic or transcriptomic approaches.

\begin{tabular}{|c|c|c|c|}
\hline \multicolumn{2}{|c|}{ Immunity } & \multirow{2}{*}{$\begin{array}{cc}\text { Leech CNS } & \text { Leech periphery } \\
\text { Tropomyosin } & \text { Tropomyosin-2 } \\
& \text { Actin-2 } \\
\text { gliarin } & \end{array}$} & \multirow{2}{*}{$\begin{array}{c}\text { Insect periphery } \\
\text { myosin II reg. light-chain } \\
\text { Actin } 5 \mathrm{C}\end{array}$} \\
\hline Cytosk. & $\begin{array}{l}\text { Microfilaments } \\
\text { IF }\end{array}$ & & \\
\hline Calcium & Calcium sensor & NCS-2/Neurocalcin & calmodulin, sarc. CaBP1 \\
\hline Metabolism & $\begin{array}{l}\text { AA/nt metabolism } \\
\text { Energy } \\
\text { Others }\end{array}$ & $\begin{array}{c}\text { AA dehydrogenase } \\
\text { ATP synthase } \beta \text { subunit } \\
\text { Acetyl transferase }\end{array}$ & $\begin{array}{l}\text { Aldehyde dehydr. } \\
\text { ATP synth. } \beta \text { subunit }\end{array}$ \\
\hline $\begin{array}{c}\text { Hsp and } \\
\text { chaperones }\end{array}$ & $\begin{array}{l}\text { Cyclophilin/PPI } \\
\text { PDI }\end{array}$ & $\begin{array}{c}\text { Cyclophilin } \\
\text { PDI } \\
\end{array}$ & $\begin{array}{l}\text { FK506-BP-PPI, Cyclophylin } \\
\text { PDI (ERp60), CaBP1-PDI }\end{array}$ \\
\hline $\begin{array}{c}\text { Metal- } \\
\text { oxidation }\end{array}$ & $\begin{array}{l}\text { Resp. molecule } \\
\text { Others }\end{array}$ & Neurohemerythrin & $\begin{array}{c}\text { Hemocyanin } \\
\text { Thioredox., Transf., ferritin }\end{array}$ \\
\hline Reg & eneration & Leech CNS & Mollusc CNS \\
\hline Cytosk. & $\begin{array}{l}\text { Microfilaments } \\
\text { IF } \\
\text { Microtubules }\end{array}$ & $\begin{array}{c}\text { Protein } 4.1 \\
\text { Synapsin } \\
\alpha \text { - and } \beta \text {-tubulin }\end{array}$ & $\begin{array}{c}\text { Tropomyosin } \\
\text { Intermediate filament } \\
\text { Tubulin } \\
\end{array}$ \\
\hline Calcium & $\begin{array}{l}\text { Calcium sensor } \\
\text { Others }\end{array}$ & Calmodulin-like & $\begin{array}{c}\text { Calmodulin, Calbindin } \\
\text { Calpain }\end{array}$ \\
\hline Metabolism & $\begin{array}{l}\text { AA/nt metabolism } \\
\text { Energy }\end{array}$ & ATPase inhibitor & $\begin{array}{l}\text { Glutamine Synthase } \\
\text { ATP Synthase }\end{array}$ \\
\hline $\begin{array}{c}\text { Hsp } \\
\text { and } \\
\text { chaperones }\end{array}$ & $\begin{array}{l}\text { Cyclophilin/PPI } \\
\text { PDI } \\
\text { Others }\end{array}$ & Hsp90 & $\begin{array}{c}\text { Cyclophilin } \\
\text { PDI } \\
\text { Hsp60, 14-3-3 }\end{array}$ \\
\hline $\begin{array}{c}\text { Metal- } \\
\text { oxidation }\end{array}$ & $\begin{array}{l}\text { Resp. molecule } \\
\text { Others }\end{array}$ & $\begin{array}{l}\text { Myohemerythrin } \\
\text { COX I }\end{array}$ & Peroxiredoxin, Ferritin \\
\hline
\end{tabular}

AA, aminoacyl; ATP synth., ATP synthase; calcin., calcineurin; CNS, central nervous system; COX I, Cyclooxygenase I; Cycloph., cyclophilin; dehydr., dehydrogenase; IF, intermediate filaments; nt, neurotransmitters; phosph., phosphatase; PK, protein kinase; PPI, peptidyl-prolyl cis-trans isomerase; sarc., sarcoplasmic; reg, regulatory; resp. molecule, respiratory molecule; Transf, transferrin. 


\section{Figure legends}

Fig. 1: Silver-stained two-dimensional gel of Hirudo medicinalis central nervous system. All significantly modulated spots are highlighted with the number of the spot. Molecular mass and pI calibration are indicated on the left and on the top of the gel respectively. The pI calibration was performed on a separate isoelectrofocusing gel strip.

Fig. 2: Changes in 2-D gel maps of leech nerve cords following the immune challenge. Enlarged views of the area of interest at the time point of modulation obtained with the Progenesis ${ }^{\mathrm{TM}}$ software.

Fig. 3: Characterization of the spot 1164: A, peptide mass fingerprint obtained by MALDI-TOF and sequences corresponding to some peptides obtained by nanoESIQ-TOF; B, results of the tryptic fragment sequences search against MSblast; C, alignment of tryptic fragment sequences from the spot 1164 with the first significant match after database searching ( $\beta$ subunit of ATP synthase of Hemicentrotus pulcherrimus, Q25117). Identical amino acids are in dark grey and homologous amino acids are in light grey. 